\title{
BioéthiqueOnline
}

\section{Doing Research with Vulnerable Populations: The Case of Intravenous Drug Users}

\section{Blake Murdoch et Timothy Caulfield}

Volume 5, 2016

URI : https://id.erudit.org/iderudit/1044290ar

DOI : https://doi.org/10.7202/1044290ar

Aller au sommaire du numéro

Éditeur(s)

BioéthiqueOnline

ISSN

1923-2799 (numérique)

Découvrir la revue

\section{Citer cet article}

Murdoch, B. \& Caulfield, T. (2016). Doing Research with Vulnerable Populations: The Case of Intravenous Drug Users. BioéthiqueOnline, 5. https://doi.org/10.7202/1044290ar

\section{Résumé de l'article}

Cet article de revue examine les préoccupations éthiques lors de recherches menées chez les usagers potentiellement vulnérables de drogues injectables (PWID) dans un contexte canadien. L'Énoncé de politique des trois Conseils : Éthique de la recherche avec des êtres humains aborde un large éventail de principes traditionnels de l'éthique de la recherche concernant les personnes vulnérables mais le fait au détriment de la clarté et de la précision. La vulnérabilité est contextuelle plutôt qu'absolue. Dans le cadre de recherche auprès des personnes vulnérables, le consentement éclairé devrait être obtenu par une personne indépendante et la compréhension devrait être vérifiée à l'aide d'un questionnaire. Les participants peuvent être vulnérables en raison de nombreux facteurs, notamment la toxicomanie, les maladies chroniques, le statut socio-économique et ethnique et le faible niveau d'éducation. La capacité de PWID à donner un consentement éclairé peut être compromis par une influence indue ou une intoxication mais les recherches existantes montrent que ni le mode ni l'ampleur de l'indemnisation n'ont un effet significatif sur les nouveaux taux de consommation de drogues. L'indemnisation peut également contribuer à dissiper la méprise thérapeutique. L'intoxication plutôt que l'influence indue est la principale préoccupation lors de l'obtention du consentement éclairé des PWID. La stigmatisation des PWID comme incapables de consentir devrait être évitée. L'exclusion paternaliste de la recherche peut nuire aux PWID et exacerber leur vulnérabilité en réduisant notre connaissance et notre capacité à les traiter spécifiquement. En tant que tel, nous devons recueillir de meilleures données concernant les effets des politiques d'éthique de la recherche. Les études menées à ce sujet devraient être axées sur les expériences, les perspectives et les besoins des participants à la recherche qui sont potentiellement vulnérables. Les comités d'éthique de la recherche au Canada devraient adopter une approche fondée sur des preuves lors de l'application du pouvoir discrétionnaire pour les propositions en recherche clinique.
Droits d'auteur (c) B Murdoch et T Caulfield, 2016

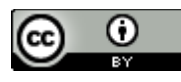

Ce document est protégé par la loi sur le droit d'auteur. L’utilisation des services d’Érudit (y compris la reproduction) est assujettie à sa politique d'utilisation que vous pouvez consulter en ligne.

https://apropos.erudit.org/fr/usagers/politique-dutilisation/ 


\section{Doing Research with Vulnerable Populations: The Case of Intravenous Drug Users}

ARTICLE (RÉVISION PAR LES PAIRS / PEER-REVIEWED)

Blake Murdoch ${ }^{1}$, Timothy Caulfield ${ }^{1}$

Reçu/Received: 1 Apr $2016 \quad$ Publié/Published: 23 Sept 2016
Éditeurs/Editors: Vanessa Chenel, Charles Dupras \& Vincent Couture
Évaluateurs externes/Peer-Reviewers: Craig L. Fry \& Sue-Ann McDonald

2016 B Murdoch, T Caulfield, Creative Commons Attribution 4.0 International License

\section{Résumé}

Cet article de revue examine les préoccupations éthiques lors de recherches menées chez les usagers potentiellement vulnérables de drogues injectables (PWID) dans un contexte canadien. L'Énoncé de politique des trois Conseils : Éthique de la recherche avec des êtres humains aborde un large éventail de principes traditionnels de l'éthique de la recherche concernant les personnes vulnérables mais le fait au détriment de la clarté et de la précision. La vulnérabilité est contextuelle plutôt qu'absolue. Dans le cadre de recherche auprès des personnes vulnérables, le consentement éclairé devrait être obtenu par une personne indépendante et la compréhension devrait être vérifiée à l'aide d'un questionnaire. Les participants peuvent être vulnérables en raison de nombreux facteurs, notamment la toxicomanie, les maladies chroniques, le statut socio-économique et ethnique et le faible niveau d'éducation. La capacité de PWID à donner un consentement éclairé peut être compromis par une influence indue ou une intoxication mais les recherches existantes montrent que ni le mode ni l'ampleur de l'indemnisation n'ont un effet significatif sur les nouveaux taux de consommation de drogues. L'indemnisation peut également contribuer à dissiper la méprise thérapeutique. L'intoxication plutôt que l'influence indue est la principale préoccupation lors de l'obtention du consentement éclairé des PWID. La stigmatisation des PWID comme incapables de consentir devrait être évitée. L'exclusion paternaliste de la recherche peut nuire aux PWID et exacerber leur vulnérabilité en réduisant notre connaissance et notre capacité à les traiter spécifiquement. En tant que tel, nous devons recueillir de meilleures données concernant les effets des politiques d'éthique de la recherche. Les études menées à ce sujet devraient être axées sur les expériences, les perspectives et les besoins des participants à la recherche qui sont potentiellement vulnérables. Les comités d'éthique de la recherche au Canada devraient adopter une approche fondée sur des preuves lors de l'application du pouvoir discrétionnaire pour les propositions en recherche clinique.

\section{Mots clés}

éthique de la recherche, consentement éclairé, vulnérable, intraveineux, consommateurs de drogues, préjudice, influence indue

\section{Abstract}

This review article considers ethical concerns when doing research on potentially vulnerable people who inject drugs (PWID) in a Canadian context. The Tri-Council Policy Statement: Ethical Conduct for Research Involving Humans broadly addresses many of the traditional ethical principles of research on vulnerable persons, but does so at the cost of clarity and precision. Vulnerability is contextual rather than absolute. When doing research with vulnerable persons, informed consent should be obtained from an independent person, and comprehension should be checked using questioning. Participants can be vulnerable due to many factors, including addiction, chronic disease, socioeconomic and racial status, and lack of education. The ability of PWID to give informed consent can be compromised by undue influence or intoxication, but existing research shows that neither the mode nor the magnitude of compensation has a significant effect on new rates of drug use. Compensation can also help dispel the therapeutic misconception. Intoxication rather than undue influence is the main concern when obtaining informed consent from PWID. The stigmatization of PWID as incapable of consent should be avoided. Paternalistic exclusion from research can harm PWID and exacerbate their vulnerability by reducing our knowledge of and ability to specifically treat them. As such, we must collect better data about the effects of research ethics policies. Studies to this effect should focus on experiences, perspectives and needs of potentially vulnerable research participants. Research ethics boards in Canada should adopt an evidence-based approach when applying discretionary power to proposals for clinical research.

\section{Keywords}

research ethics, informed consent, vulnerable, intravenous, drug users, harm, undue influence 
Responsabilités des évaluateurs externes

Les évaluations des examinateurs externes sont prises en considération de façon sérieuse par les éditeurs et les auteurs dans la préparation des manuscrits pour publication. Toutefois, être nommé comme examinateur n'indique pas nécessairement l'approbation de ce manuscrit. Les éditeurs de BioéthiqueOnline assument la responsabilité entière de l'acceptation finale et la publication d'un article.

\section{Peer-reviewer responsibilities}

Reviewer evaluations are given serious consideration by the editors and authors in the preparation of manuscripts for publication. Nonetheless, being named as a reviewer does not necessarily denote approval of a manuscript; the editors of BioéthiqueOnline take full responsibility for final acceptance and publication of an article.

Affiliations des auteurs / Author Affiliations

${ }^{1}$ Health Law Institute, Faculty of Law, University of Alberta, Edmonton, Canada

\section{Correspondance / Correspondence}

Timothy Caulfield, caulfield@ualberta.ca

\section{Remerciements}

Ce travail a été réalisé dans le cadre du projet de recherche Collaborative Research \& Innovation Opportunities (CRIO) dirigé par Dr. Michael Houghton et Dr Lorne Tyrrell et financé par Alberta Innovates Health Solutions (AlHS). Les auteurs tiennent à remercier $\mathrm{Dr}$ Michael Houghton et Dr Tyrrell pour leurs commentaires et suggestions constructifs.

Conflit d'intérêts

Aucun déclaré

\section{Acknowledgements}

This work was completed as part of a Collaborative Research \& Innovation Opportunities (CRIO) research project led by Dr. Michael Houghton and Dr. Lorne Tyrrell and funded by Alberta Innovates Health Solutions (AIHS). The authors would like to thank Dr. Houghton and Dr. Tyrrell for their helpful comments and suggestions.

\section{Conflicts of Interest}

None to declare

\section{Introduction}

Intravenous drug addiction causes serious vulnerability in society, producing high rates of chronic disease such as HIV, Hepatitis B \& $\mathrm{C}$ and tuberculosis, as well as social deterioration and psychological harm [1-7]. Approximately $50 \%$ of people who inject drugs (PWID) die within a 30 -year follow-up period [8]. Due to these realities, recruitment of PWID has been and continues to be of considerable importance to clinical research; for example, decades of research with PWID has led to many new discoveries about HIV prevention [9]. Including PWID as research participants can allow researchers to study specific illnesses more directly, while, at the same time, potentially providing benefits to the PWID community in the short and long term. However, ethical issues arise in these circumstances.

The treatment of vulnerable individuals in research has been a serious concern of governments and bioethicists ever since the public unveiling of grievous misconduct in historical clinical experimentation. Key atrocities among those publicized were Nazi experimentation, American research on "conscientious objectors", the Tuskegee syphilis experiment, and American hepatitis experimentation on disabled children [10,11]. Over the decades, most nations have enacted legislation and/or policy guidelines requiring individuals deemed vulnerable to receive special treatment in clinical research, or to be excluded altogether. In Canada, the treatment of vulnerable populations in research is governed by the Canadian Panel on Research Ethics' Tri-Council Policy Statement on Ethical Conduct for Research Involving Humans, $2^{\text {nd }}$ Edition (TCPS2), along with the ethics committees and review boards that discretionarily apply it [12]. Researchers also self-govern using both new developments in ethics, and existing ethical norms from domestic and international scientific traditions. On the international scale, the World Medical Association's (WMA) Helsinki Declaration is a foundational document for human research ethics; it consists of a series of principles for ethical human experimentation endorsed by the WMA's general assembly [13]. These policies, among many others, seek to ensure that vulnerable populations involved in research are afforded fair and just treatment. 
In this review, we examine the existing literature on the ethics of vulnerability in research, as well as the important vulnerability provisions of the TCPS2. Subsequently, we review issues surrounding the ethics of research on PWID. Finally, we discuss implications of the literature, and consider criticisms of existing ethical and regulatory frameworks in relation to PWID. We conclude with suggestions as to a way forward for future research in vulnerable population ethics.

\section{General Concepts in Research on Vulnerable Populations}

Attempts to define vulnerability in measurable ways have met with little to no consensus $[14,15]$. Some reasonably suggest that vulnerability is not static, but rather indexical: not absolute, but contextual [14,16]. The Helsinki Declaration does not define vulnerability, but states that "all vulnerable groups and individuals should receive specifically considered protection" [13]. It also states that medical research on a vulnerable group is only acceptable if three criteria are met: the research is responsive to the health needs or priorities of this group, the research cannot be carried out on a nonvulnerable group, and the group would stand to benefit from resultant knowledge, practices or interventions [13]. These criteria seek to ensure a favourable ratio of expected benefit to burden for vulnerable groups [17].

Informed consent is a pillar of research ethics. A person obtaining informed consent should be independent and free from conflicts of interest [13]. The process generally consists of providing all material information, ascertaining that this information is clearly understood, confirming capacity and competency, and ensuring voluntariness [18]. Canadian common law further requires that in a medical context, information related to the nature of a procedure, its risks and benefits, and alternative treatments that a reasonable person in the patient's position would want to know must be disclosed [19]. Vulnerable individuals may be unable to understand information, may lack capacity, or may be prone to experiencing undue influence or coercion that essentially renders their consent involuntary. Because of these issues, obtaining a valid, legal consent can be a challenge. Greater care is required to ensure that all the elements of consent are present. In addition, it is not always possible to determine vulnerability prior to the commencement of a study, and a repetitive process can aid in ensuring eventual identification [16]. As such, the process of obtaining informed consent should be ongoing [16].

Ethical judgments about research are influenced by competing concepts and can often be contradictory (e.g., a researcher's attempt to ensure non-maleficence may lead to paternalistic behaviour that violates the principle of respect for a participant's autonomy) [20]. However, there is much support for the notion that research on a vulnerable group is only justified when that group stands to benefit from the potential results of the research $[13,21,22]$. If the vulnerable group does not stand to receive any benefit, and instead the benefit will go to another group, using members of the vulnerable group as participants is potentially an abusive reduction of the participants to "human subject fodder" [23]. Furthermore, some suggest that dominant research methodologies can themselves exacerbate vulnerability, and that a focus on developing a culturally safe space for research is crucial to prevent harm and ensure benefit [24].

From a Canadian legal perspective, researchers are likely to have fiduciary responsibilities toward participants when engaging in clinical research [25]. Along with this fiduciary relationship comes a duty of care, and a duty not to abuse the power imbalance inherent to the clinician-patient relationship [26]. A fiduciary relationship has three components: the fiduciary has scope for the exercise of some discretion or power, the fiduciary can unilaterally exercise that power or discretion so as to affect the beneficiary's legal or practical interests, and the beneficiary is peculiarly vulnerable or at the mercy of the fiduciary holding the discretion or power [26]. As such, the law of fiduciaries is relevant to decisions regarding vulnerable persons in research. Its relevance to decision-making when assessing a particular vulnerable person for participation likely depends on the probability of the proposed research causing harm. The principles of fiduciary law appear to have been subsumed into, 
or are at least reflected in bioethics policy. Nonetheless, the presence of fiduciary responsibility can act to increase or intensify obligations, as well as the consequences for failing to meet them.

\section{The Tri-Council Policy Statement}

The concept of vulnerability is part of the TCPS2's overarching principles of Respect for Persons, Concern for Welfare, and Justice [12]. Vulnerability is defined therein as "a diminished ability to fully safeguard one's own interests in the context of a specific research project" [12]. The TCPS2 goes on to state that potential causes of this include "limited decision-making capacity or limited access to social goods, such as rights, opportunities and power" [12]. Important mentions of vulnerability exist in multiple chapters of the TCPS2, and can be reviewed in Table 1.

A few specific mentions of vulnerability are crucial and demand consideration. Article 4.7 is the primary vulnerability provision, and importantly mentions that vulnerability depends on the context of research. It demands that, once vulnerability is established in said context, a potential participant should neither be "inappropriately included" not "automatically excluded" from research [12]. This wording could be considered vague, as we have no indication what "inappropriate" is from the document. Vagueness of this type is common in bioethics policy documents, and while it may grant a wide berth of discretion to governing bodies, it also can lead to confusion and/or undue caution among researchers.

Within Chapter 1 is a list of groups "historically" considered vulnerable. This list includes extremely broad categories such as "women" and "the elderly" [12]. Yet, in Chapter 4 the TCPS2 prohibits stereotyping based solely on assumptions about a group to which a participant belongs, and reiterates the situational nature of vulnerability [12]. Chapter 3 speaks to the requirements of informed consent when dealing with vulnerable persons. If there is a suspicion that an individual lacks capacity or may be unduly influenced in the consent process, special steps must be taken: these include, inter alia, demonstrating minimal risk and demonstrating that the research is being carried out for the direct benefit of the participant [12].

Chapter 9 appears to place the onus on researchers to find ways to include in research persons from vulnerable groups within specific or isolated territorial or organizational communities [12]. Barriers often exist in these circumstances, but such communities also often have the most to gain from the benefits of research [12]. Finally, Chapter 11 requires clinician-researchers to avoid overstating the benefits of research and to avoid therapeutic misconception, which occurs when participants mistakenly believe that the research is legitimate medical treatment even though there may be no clinical benefit whatsoever [12].

Overall, the TCPS2 broadly addresses many of the issues that have been noted around the traditional ethics of vulnerability, but does so at the cost of clarity and precision. This lack of precision could cause a chilling effect on the amount of research performed using PWID, which, as we will discuss in a later section, could result in harm. 
Table 1 - Highlights: Mentions of Vulnerability in the Tri-Council Policy Statement

\begin{tabular}{|c|c|}
\hline Chapter & Statement / Comment \\
\hline 1 & $\begin{array}{l}\text { Respect for Persons requires involving individuals in circumstances of vulnerability in decision } \\
\text { making where possible. This may include asking about their feelings regarding participation and/or } \\
\text { for their assent. }\end{array}$ \\
\hline 1 & $\begin{array}{l}\text { Vulnerability is often caused by limited decision-making capacity, or limited access to social } \\
\text { goods, such as rights, opportunities and power. Individuals or groups in vulnerable circumstances } \\
\text { have historically included children, the elderly, women, prisoners, those with mental health issues } \\
\text { and those with diminished capacity for self-determination. Ethnocultural minorities and those who } \\
\text { are institutionalized are other examples of groups who have, at times, been treated unfairly and } \\
\text { inequitably in research, or have been excluded from research opportunities. People or groups } \\
\text { whose circumstances cause them to be vulnerable or marginalized may need to be afforded } \\
\text { special attention in order to be treated justly in research. }\end{array}$ \\
\hline 2 & $\begin{array}{l}\text { [Vulnerable persons'] inclusion in research should not exacerbate their vulnerability (see Article } \\
4.7 \text { ). }\end{array}$ \\
\hline 3 & $\begin{array}{l}\text { When participants are vulnerable to risks from third parties (e.g., authoritarian regimes, gang } \\
\text { leaders, employers) on account of their involvement in research, researchers should ensure that } \\
\text { copies of field materials are kept in secure locations. }\end{array}$ \\
\hline 3 & $\begin{array}{l}\text { In considering the need for an alteration to consent requirements, researchers and REBs should } \\
\text { also consider whether the prospective participants (as individuals, groups, or populations) are in } \\
\text { vulnerable circumstances (see Article 4.7). The existence of vulnerable circumstances may } \\
\text { require greater effort to minimize risks to participants and/or maximize potential benefits (see } \\
\text { Chapter 2, Section B). }\end{array}$ \\
\hline 3 & $\begin{array}{l}\text { Respect for Persons and Concern for Welfare entails particular ethical obligations to individuals in } \\
\text { vulnerable circumstances. Such obligations often translate into special procedures to promote and } \\
\text { protect their interests. This may include the development of consent materials that are appropriate } \\
\text { to the cognitive and communication abilities of prospective participants. }\end{array}$ \\
\hline 4 & $\begin{array}{l}\text { In addition to the vulnerability that arises from their developmental stage, children may also lack } \\
\text { the decision-making capacity to decide whether or not to participate in research (see Article 4.6). }\end{array}$ \\
\hline 4 & $\begin{array}{l}\text { [Article 4.7] Individuals or groups whose circumstances may make them vulnerable in the } \\
\text { context of research should not be inappropriately included or automatically excluded from } \\
\text { participation in research on the basis of their circumstances. }\end{array}$ \\
\hline 4 & $\begin{array}{l}\text { Individuals should not automatically be considered vulnerable simply because of assumptions } \\
\text { made about the vulnerability of the group to which they belong. Their particular circumstances } \\
\text { shall be considered in the context of the proposed research project. }\end{array}$ \\
\hline 4 & $\begin{array}{l}\text { Researchers should anticipate, to the best of their ability, needs of participants, groups and their } \\
\text { communities that might arise in any given research project. Especially when groups, and their } \\
\text { communities, have a wide range of pressing needs due to their low socioeconomic circumstances, } \\
\text { these needs can present significant ethical challenges for researchers. An equitable distribution of } \\
\text { research benefits (discussed below) can help ensure that individuals, groups and communities } \\
\text { whose circumstances may make them vulnerable in the context of research are not } \\
\text { inappropriately included in research based on these circumstances. }\end{array}$ \\
\hline 9 & $\begin{array}{l}\text { Groups or individuals whose circumstances may make them vulnerable or marginalized within } \\
\text { territorial or organizational communities should not be deprived of opportunities to participate in, } \\
\text { and influence, research affecting their welfare. For example, people living with HIVIAIDS, } \\
\text { impoverished youth or women who have suffered abuse may experience barriers to participation. }\end{array}$ \\
\hline 9 & $\begin{array}{l}\text { Structural barriers may prevent access to, and participation in, research. [...] The least } \\
\text { organizationally developed communities are the most vulnerable to exploitation. Research } \\
\text { undertaken in these circumstances should strive to enhance capacity for participation. }\end{array}$ \\
\hline 11 & $\begin{array}{l}\text { It is important that clinician-researchers take care not to overplay the benefits of research } \\
\text { participation to patients in vulnerable circumstances, who may be misled to enter trials with false } \\
\text { hopes. }\end{array}$ \\
\hline
\end{tabular}




\section{Vulnerability in Clinical Research on Intravenous Drug Users}

Determining the vulnerability of PWID is a nuanced task because there is no consistent and inherent physical vulnerability within the population. Instead, vulnerabilities can arise from multiple psychological and social factors. Importantly, drug abuse disproportionately affects poor, male, urban and ethnic minority persons [27-29]. These persons can be doubly vulnerable due to historical and current institutional forms of oppression that further diminish autonomy and increase risk of disease [29-31]. Lack of knowledge and education also contributes to vulnerability: for example, one Canadian study found that, among illicit drug users who tested positive for hepatitis $\mathrm{C}$ virus in two Canadian community clinics, the most common reason for not seeking treatment was a lack of information about the virus or available treatments [32].

The most obvious questions regarding recruiting PWID for research revolve around the ability to give informed consent [33]. These participants are potentially at risk of experiencing undue influence on decision-making due to intoxication, cognitive deficits from long-term substance abuse, comorbid psychiatric disorders, and other factors [29]. Even when research does not involve the administration of addictive substances, there is a risk that participation will be unduly coerced in the addicted participant's mind due to the desire to acquire the resources, e.g., money, needed to obtain addictive substances [34]. Fry and colleagues [35] suggest that payments should not be provided as a reward for risk or harm, should be scrutinized when they could create additional risks, and should only be provided for any time and out-of-pocket expenses spent on the study.

It has also been suggested that currency should not be provided as compensation to PWID, and should be substituted with items like vouchers or food [34,36]. Yet, such compensation reflects negative stereotypes about these participants' irresponsibility and untrustworthiness, and places researchers in a moralistic position that both fails to afford research participants the respect of control and reinforces negative stigma [34,37]. Although more research is needed, studies have found that neither the mode, i.e., cash or gift certificates, nor the magnitude of payment had a significant effect on rates of new drug use or perceptions of coercion $[35,36,39]$. One study found "no evidence that payment is coercive, undermines voluntariness, or increases drug use in the short-term" [38]. Moreover, payment is an important motivating factor for reaching substance users and maintaining their attendance at follow up visits [38-41]. This is consistent with general population studies on the effects of payment: e.g., one study found that approximately $30 \%$ of participants in a large controlled trial reported money as the main motivation for participating, but less than $5 \%$ felt the financial incentive was coercive [40]. Monetary incentives also carry the extra benefit of helping to dispel therapeutic misconception [29]. Assumptions about reasons for participating in research of PWID often fail to account for evidence that they participate in part with the hope of benefiting others [42]. At least two studies show that such individuals, except when intoxicated, are approximately as capable of making rational decisions to participate in research as non-substance abusing participants, so long as the study does not involve administration of addictive substances $[29,43,44]$.

Nonetheless, the possibility of intoxication at the time of obtaining consent poses a serious risk to any clinical study. Alcohol intoxication, for example, has been shown to affect suggestibility, risk-taking and moral reasoning [45]. Intoxication is not a straightforwardly identifiable state that can be easily measured using biochemical methods; it depends upon individual differences, inter alia [45]. More empirical research is needed to establish the effects of intoxication by various drugs, or combinations thereof. Suggestions for ensuring proper consent when faced with potential intoxication include checking understanding, extending the timeframe for consent and its withdrawal, training staff to check for signs of intoxication, and excluding from the outset those who are obviously intoxicated $[45,46]$. 


\section{Discussion}

It is clear that special procedures are necessary when engaging in research with PWID. Perhaps the most important procedures are ensuring the presence of a person independent of the research team to seek consent, screening for signs of intoxication, and checking comprehension through questioning. Yet, many concerns about recruitment incentives and the ability to give informed consent may be inflated. Fisher found that street drug users "share with investigators an appreciation for foundational moral principles guiding research regulation" and that they "have the ability and willingness to grapple with core dimensions of morality" [47]. In hindsight, it is possible that some policies for treatment of "vulnerable persons" are historically founded, in part, in discriminatory (racist, classist, sexist, etc.) presumptions [48]. The recent literature has been quite critical of existing research ethics practices surrounding vulnerability.

Some critics suggest that there is no logical or empirical basis to certain common categorizations of vulnerability, and that they are often overbroad [49,50]. Indeed, many foundational documents of bioethics enumerate lists of vulnerable groups, but lack any explanation or analysis as to why they are vulnerable $[12,50]$. For example, pregnant women are consistently categorized as vulnerable in many jurisdictions, even in the face of evidence that this is mostly not the case [49]. Such categorizations may have a cascading effect, as, over time, women in general may be stigmatized as vulnerable and suffer as well [49,51]. This broad stigmatization has potentially been wrongly imposed on PWID, given aforementioned evidence indicating that any given individual is likely to be capable of informed consent $[29,43,44]$.

Paternalism is a related issue. Juritzen posits that government control through ethics committees and their associated "pastoral power" molds researchers into self-regulating agents that are prone to paternalistic attitudes [52]. As such, the application of ethical principles in decisions surrounding the inclusion or exclusion of vulnerable subjects often fails to account for the perspective and ethics of the subjects themselves $[53,54]$. The perspectives of PWID could be used to identify nonobvious consequences of specific research practices, such as participant distress, violation of privacy or diminishment of autonomy [29,37].

\section{Selected Critical Quotes from the Literature}

...this erroneous characterization of pregnant women as "vulnerable" and its associated protections have not only impeded vital research for pregnant women and their fetuses, but have also negatively affected the inclusion of all women in clinical research. -Schonfeld, 2013

...regulators and institutional review boards (IRBs) often target groups for protections; but in reality we are dealing with unique individuals who have become part of a heterogeneous group only because of the sampling intentions of a researcher. -Dubois et al, 2012

...the paternalistic attitudes that prevent vulnerable people from being recruited into a study are also denying them their basic right to autonomy, their right to decide for themselves whether or not to participate in a study, as well as exposing them to the risk of marginalization. -Alexander, 2010

Several foundational documents of bioethics mention the special obligation researchers have to vulnerable research participants. However, the treatment of vulnerability offered by these documents often relies on enumeration of vulnerable groups rather than an analysis of the features that make such groups vulnerable. -Lange, 2013

Persons categorized as belonging to vulnerable groups are potentially harmed, and rendered more vulnerable, by their exclusion from research $[55,56]$. This harm is caused due to a resultant failure to understand these groups and provide them with the benefits of research [57]. Examples of identified affected groups include pregnant women and the obese $[49,51,57]$. The TCPS2 evidently tries to address this issue in article 4.7, where it states that vulnerable people should not be automatically excluded from research. However, it is questionable whether this is enough to prevent the compounding effect of vulnerability, given the fact that extra funds and resources must be applied to actively include vulnerable persons and to satisfy the TCPS2's special requirements for informed consent that accompany their inclusion [57]. There is often a financial disincentive to including 
vulnerable groups in research, and when combined with paternalistic attitudes this can prevent vulnerable groups from being studied. Fear of potential legal liability under fiduciary law can further dissuade researchers from including vulnerable participants. It is unclear to what extent PWID, already severely disadvantaged, have been harmed through exclusion from research. For example, it is unclear whether their rate of disease is higher due to a lack of access to the education afforded by participation in research [32].

Major research undertakings can be relocated to more lenient jurisdictions abroad in order to carry out research deemed high risk or problematic at home $[58,59]$. This "research tourism" is a potential pitfall of restrictive policies towards research on vulnerable populations. The Helsinki Declaration helps diminish this problem by providing consistent overarching guidelines, but fails to solve it. In instances where research is undertaken in other jurisdictions, vulnerable persons may be slow to receive the benefits of research, or may fail to receive them altogether.

\begin{tabular}{|l|l|}
\hline \multicolumn{2}{|c|}{ Potential Benefits and Harms of Research on PWID } \\
\hline Potential Benefits & Potential Harms \\
\hline $\begin{array}{l}\text { Generation of new clinical knowledge, more } \\
\text { rapidly }\end{array}$ & Therapeutic misconception \\
\hline Reduction in disease in PWID populations & Undue influence to participate in risky research \\
\hline Increased PWID resources through education & Physical harm due to clinical error \\
\hline $\begin{array}{l}\text { Increased PWID resources through } \\
\text { compensation }\end{array}$ & Increase in addiction due to acquisition of resources \\
\hline $\begin{array}{l}\text { Better understanding of issues specific to } \\
\text { PWID }\end{array}$ & $\begin{array}{l}\text { Paternalism, and related failure to meet the needs of } \\
\text { PWID }\end{array}$ \\
\hline
\end{tabular}

\section{Conclusions}

In our view, the likelihood that harm is caused by the exclusion from research of persons who are broadly stereotyped as vulnerable creates an imperative to collect better data as to the effects of relevant research ethics policies. In Canada, the broad nature of the TCPS2 creates space for significant discretionary action by research ethics boards. This top down approach may often be based more on principles and hypotheticals than data. Further empirical research into the effects of excluding vulnerable persons like PWID from clinical research would help to either address or support serious existing criticisms of current systems $[37,60]$. It seems only logical that we collect data about the consequences of established ethical standards in science, rather than relying on historical beliefs as to the proper application of axioms [37,60]. Simply engaging in this type of research will help to alleviate concerns of paternalism, because such research would certainly focus on the experiences, perspectives and needs of research participants [61]. Such engagement could be facilitated through collaborative work between medical and social science researchers, and might for example include interviewing and surveying of persons subsequent to ethics-based exclusion from particular research projects. On a larger scale, further study of rates of research participation could prove useful, especially if data is then related to rates of health and disease as compared to baseline populations. Local substance abuse organizations would be important contact points for establishing fruitful relationships.

Ensuring that PWID and other vulnerable persons are recruited for clinical research is a shared responsibility of both researchers and frontline healthcare providers [56,62]. However, administrative guidelines act to discourage or prohibit such recruitment. We suggest that research ethics boards in Canada adopt a more evidence-based approach when applying their discretionary power to proposals for clinical research. As more data on the consequences of specific research policies is collected, evidence-informed policy options will emerge that can guide changes to the future of Canadian clinical research ethics. 


\section{List of References}

1. Salvalaggio G, Dong K, Vandenberghe C, Kirkland S, Cummings GG, McKim R, Taylor M. Effect of a knowledge translation intervention on physician screening, brief intervention, and referral to treatment behaviour in a socioeconomically disadvantaged setting. Canadian Journal of Addiction. 2015;6(1):7-14.

2. Balderston R, Crockford D. Management of the psychotic substance using patient. Canadian Journal of Addiction. 2014;5(2):5-9.

3. Deiss RG, Rodwell TC, Garfein RS. Tuberculosis and illicit drug use: review and update. Clinical Infectious Diseases. 2009;48:72-82.

4. Kinner SA, George J, Campbell G, Degenhardt L. Crime, drugs and distress: patterns of drug use and harm among criminally involved injecting drug users in Australia. Australian and New Zealand Journal of Public Health. 2009;33(3):223-227.

5. Darke S, Kaye S, McKetin R, Duflou J. Major physical and psychological harms of methamphetamine use. Drug and Alcohol Review. 2008;27(3):253-262.

6. Mathers BM, Degenhardt L, Phillips B, Wiessing L, Hickman M, Strathdee SA, Wodak A, Panda S, Tyndall M, Toufik A, Mattick RP. Global Epidemiology of injecting drug use and HIV among people who inject drugs: a systematic review. The Lancet. 2008;372(9651):1733-1745.

7. Shepard CW, Finelli L, Alter MJ. Global epidemiology of hepatitis C virus infection. The Lancet Infectious Diseases. 2005;5(9):558-567.

8. Truskowkska E, McCarron P, Konovalov P, Galander T, Lyons S, Keenan E, Smyth BP. Casecontrol study of risks and causes of death amongst opioid dependent patients on methadone maintenance treatment. Canadian Journal of Addiction. 2015;6(3):18-26.

9. Des Jarlais DC, Friedman SR. Fifteen years of research on preventing HIV infection among injecting drug users: what we have learned, what we have not learned, what we have done, what we have not done. Public Health Reports. 1998 Jun;113(Suppl 1):182.

10. Reel K. Clinical considerations for allied professionals on research ethics - Vulnerable research participant populations: Ensuring ethical recruitment and enrolment. Heart Rhythm. 2011;8(6):947-950.

11. Krugman S, Shapiro S. Experiments at the Willowbrook State School. The Lancet. 1971 297(7706):966-967.

12. Canadian Institutes of Health Research, Natural Sciences and Engineering Research Council of Canada, and Social Sciences and Humanities Research Council of Canada. Tri-Council Policy Statement: Ethical Conduct for Research Involving Humans. December 2014.

13. World Medical Association. WMA Declaration of Helsinki - Ethical Principles for Medical Research Involving Human Subjects. Geneva: World Medical Association; 2013.

14. Welch MJ, Lally R, Miller JE, Pittman S, Brodsky L, Caplan AL, Uhlenbrauck G, Louzao DM, Fischer $\mathrm{JH}$, Wilfond $\mathrm{B}$. The ethics and regulatory landscape of including vulnerable populations in pragmatic clinical trials. Clinical Trials. 2015;12(5):502-510.

15. Ruof MC. Vulnerability, vulnerable populations, and policy. Kennedy Institute of Ethics Journal 2004;14(4):411-425.

16. Nordentoft HM, Kappel N. Vulnerable participants in health research: methodological and ethical challenges. Journal of Social Work Practice. 2011;25(3):365-376.

17. Gostin L. Ethical principles for the conduct of human subject research: population-based research and ethics. The Journal of Law, Medicine \& Ethics. 2007;19(3-4):191-201.

18. Ketefian S. Ethical considerations in research. Focus on vulnerable groups. Investigación y Educación en Enfermería. 2015;33(1):164-172.

19. Reib/ v. Hughes, [1980] 2 SCR 880, 1980 CanLII 23 (SCC).

20. Smith L. How ethical is ethical research? Recruiting marginalized, vulnerable groups into health services research. Journal of Advancing Nursing. 2008;62(2):248-257.

21. Nickel P. Vulnerable populations in research: the case of the seriously ill. Theoretical Medicine and Bioethics. 2006;27:245-264. 
22. Zion D, Gillam L, Loff B. The Declaration of Helsinki, CIOMS and the ethics of research on vulnerable populations. Nature Medicine. 2000;6(6):615-617.

23. Stone TH. Currents in contemporary ethics. The Journal of Law, Medicine and Ethics. 2003;31(1):149-153.

24. Wilson D, Neville $S$. Culturally safe research with vulnerable populations. Contemporary Nurse. 2009;33(1):69-79.

25. Miller PB, Weijer C. Fiduciary obligation in clinical research. Journal of Law, Medicine \& Ethics. 2006;34(2):424-440.

26. Norberg v. Wynrib, [1992] 2 SCR 226, 1992 CanLII 65 (SCC).

27. Health Canada. Canadian Tobacco, Alcohol and Drugs Survey (CTADS), Summary of results for 2013. 2015.

28. U.S. Department of Health and Human Services. Results from the 2011 National Survey on Drug Use and Health: Summary of National Findings. 2012.

29. Fisher CB. Ethics in drug abuse and related HIV risk research. Applied Developmental Science. 2004;8(2):91-103.

30. Moore LW, Miller M. Initiating research with doubly vulnerable populations. Journal of Advanced Nursing. 1999;30(5):1034-1040.

31. Flaskerud JH, Winslow BJ. Conceptualizing vulnerable populations health-related research. Nursing Research. 1998;47(2):69-78.

32. Grebely J, Genoway KA, Raffa JD, Dhadwal G, Rajan T, Showler G, Kalousek K, Duncan F, Tyndall MW, Fraser C, Conway B, Fischer B. Barriers associated with the treatment of hepatitis C virus infection among illicit drug users. Drug and Alcohol Dependence. 2008;93(12):141-147.

33. Fisher CB, Oransky M, Mahadevan M, Singer M, Mirhej G, Hodge D. Marginalized populations and drug addiction research: realism, mistrust and misconception. IRB: Ethics and Human Research. 2008;30(3):1-9.

34. Ritter AJ, Fry CL, Swan A. The ethics of reimbursing injecting drug users for public health research interviews: what price are we prepared to pay? International Journal of Drug Policy. 2003;14(1):1-3.

35. Fry CL, Hall W, Ritter A, Jenkinson R. The ethics of paying drug users who participate in research: a review and practical recommendations. Journal of Empirical Research on Human Research Ethics. 2006;1(4):21-35.

36. Laimputtong P. Researching the Vulnerable: A Guide to Sensitive Research Methods. London: SAGE Publications, Ltd; 2007.

37. Dubois JM, Beskow L, Campbell J, Dugosh K, Festinger D, Hartz S, James R, Lidz C. Restoring balance: a consensus statement on the protection of vulnerable research participants. American Journal of Public Health. 2012;102(12):2220-2225.

38. Festinger DS, Marlowe DB, Croft JR, Dugosh KL, Mastro NK, Lee PA, DeMatteo DS, Patapis NS. Do research payments precipitate drug use or coerce participation? Drug \& Alcohol Dependence. 2005;78:275-281.

39. Festinger D, Marlowe DB, Dugosh KL, Croft JR, Arabia PL. Higher magnitude cash payments improve research follow-up rates without increasing drug use or perceived coercion. Drug and Alcohol Dependence. 2008;96:128-135.

40. Byrne MM, Croft JR, French MT, Dugosh KL, Festinger DS. Development and preliminary results of the Financial Incentive Coercion Assessment questionnaire. Journal of Substance Abuse Treatment. 2012;43:86-93.

41. Anderson EE, DuBois JM. The need for evidence-based research ethics: A review of the substance abuse literature. Drug and Alcohol Dependence. 2007;86(2-3):95-105.

42. Fry C, Dwyer R. For love or money? An exploratory study of why injecting drug users participate in research. Addiction. 2001;96(9):1319-1325. 
43. MacQueen KM, Vanichseni S, Kitayaporn D, Lin LS, Buavirat A, Naiwatanakul T, Raktham S, Mock P, Heyward WL, Des Jarlais DC, Choopanya K, Matro TD. Willingness of injection drug users to participate in an HIV vaccine efficacy trial in Bangkok, Thailand. Journal of Acquired Immune Deficiency Syndrome. 1999;21:243-251.

44. Harrison K, Vlahov D, Jones K, Charron K, Clements M. Medical eligibility, comprehension of the consent process and retention of injection drug users recruited for an HIV vaccine trial. Journal of Acquired Immune Deficiency Syndrome and Human Retrovirology. 1995;10:386390.

45. Aldridge J, Charles V. Researching the intoxicated: informed consent implications for alcohol and drug research. Drug and Alcohol Dependence. 2008;93:191-196.

46. Dunn LB, Jeste DV. Enhancing informed consent for research and treatment. Neropsychopharmacology. 2001;24:595-607.

47. Fisher CB. Addiction research ethics and the Belmont principles: do drug users have a different moral voice? Substance Use \& Misuse. 2011;46(6):728-741.

48. Demi AS, Warren NA. Issues in conducting research with vulnerable families. Western Journal of Nursing Research. 1995;17(2):188-202.

49. Schonfeld T. The perils of protection: vulnerability and women in clinical research. Theoretical Medical Bioethics. 2013;34:189-206.

50. Lange MM, Rogers W, Dodds S. Vulnerability in research ethics: a way forward. Bioethics. 2013;27(6):333-340.

51. Dennis BP. The origin and nature of informed consent: Experiences among vulnerable groups. Journal of Professional Nursing. 1999;15(5):281-287.

52. Juritzen TI, Grimen H, Heggen K. Protecting vulnerable research participants: A Foucaultinspired analysis of ethics committees. Nursing Ethics. 2011;18(5):640-650.

53. Walker S, Read S. Accessing vulnerable research populations: an experience with gatekeepers of ethical approval. International Journal of Palliative Nursing. 2011;17(1):14-18.

54. Alexander JA. 'As long as it helps somebody': why vulnerable people participate in research. International Journal of Palliative Nursing. 2010;16(4):173-178.

55. Ravinetto RM, Afolabi MO, Okebe J, Van Nuil JI, Lutumba P, Mavoko HM, Nahum A, Tinto H, Addissie A, D'Alessandro U, Grietens KP. Participation in medical research as a resourceseeking strategy in socio-economically vulnerable communities: call for research and action. Tropical Medicine and International Health. 2015;20(1):63-66.

56. UyBico SJ, Pavel S, Gross CP. Recruiting vulnerable populations into research: a systematic review of recruitment interventions. Journal of General Internal Medicine. 2007;22(6):852-863.

57. Cook D, Moore-Cox A, Xavier D, Lauzier F, Roberts I. Randomized trial in vulnerable populations. Clinical Trials. 2008;5(1):61-69.

58. Schuklenk U. Protecting the vulnerable: testing times for clinical research ethics. Social Science \& Medicine. 2000;51(6):969-977.

59. Angell $M$. The ethics of clinical research in the third world. The New England Journal of Medicine. 1997;337(12):847-849.

60. Anderson EE, Sieber JE. The need for evidence-based research ethics. The American Journal of Bioethics. 2009;9(11):60-62.

61. Anderson DG, Hatton DC. Accessing vulnerable populations for research. Western Journal of Nursing Research. 2000;22(2):244-251.

62. Sutton LB, Erlen JA, Glad JM, Siminoff LA. Recruiting vulnerable populations for research: Revisiting the ethical issues. Journal of Professional Nursing. 2003;19(2):106-112. 